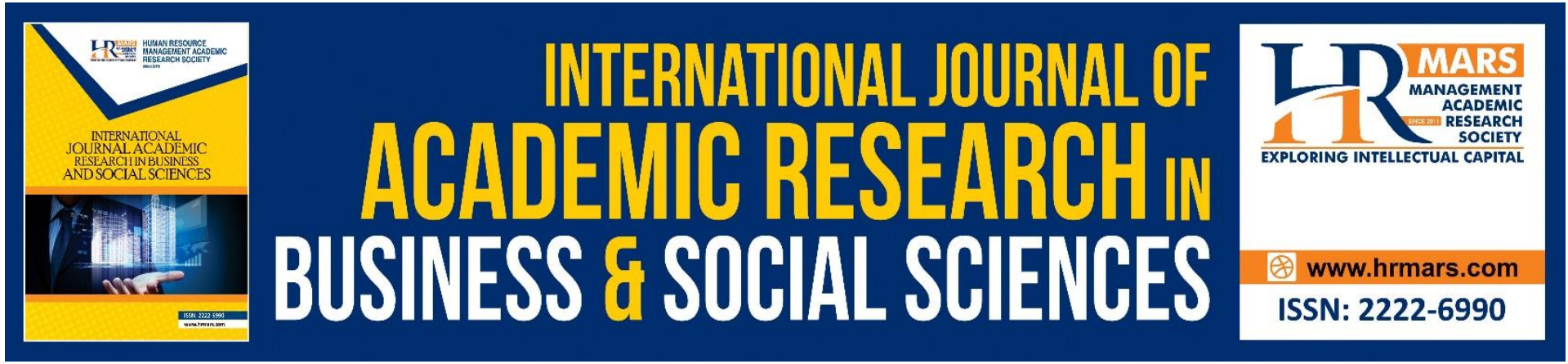

\title{
Wakalah bi al-Istithmar: A Case Study of Wafiyah Investment Account Bank Islam Malaysia Berhad (BIMB)
}

\author{
Marina Abu Bakar \& Nur Fatin Husna Mohd Nasir
}

To Link this Article: http://dx.doi.org/10.6007/IJARBSS/v11-i7/10598

DOI:10.6007/IJARBSS/v11-i7/10598

Received: 25 May 2021, Revised: 28 June 2021, Accepted: 10 July 2021

Published Online: 26 July 2021

In-Text Citation: (Bakar \& Nasir, 2021)

To Cite this Article: Bakar, M. A., \& Nasir, N. F. H. M. (2021). Wakalah bi al-Istithmar: A Case Study of Wafiyah Investment Account Bank Islam Malaysia Berhad (BIMB). International Journal of Academic Research in Business and Social Sciences, 11(7), 1412-1436.

Copyright: (c) 2021 The Author(s)

Published by Human Resource Management Academic Research Society (www.hrmars.com)

This article is published under the Creative Commons Attribution (CC BY 4.0) license. Anyone may reproduce, distribute, translate and create derivative works of this article (for both commercial and non-commercial purposes), subject to full attribution to the original publication and authors. The full terms of this license may be seen at: http://creativecommons.org/licences/by/4.0/legalcode

Vol. 11, No. 7, 2021, Pg. 1412 - 1436

http://hrmars.com/index.php/pages/detail/IJARBSS

JOURNAL HOMEPAGE

Full Terms \& Conditions of access and use can be found at http://hrmars.com/index.php/pages/detail/publication-ethics 


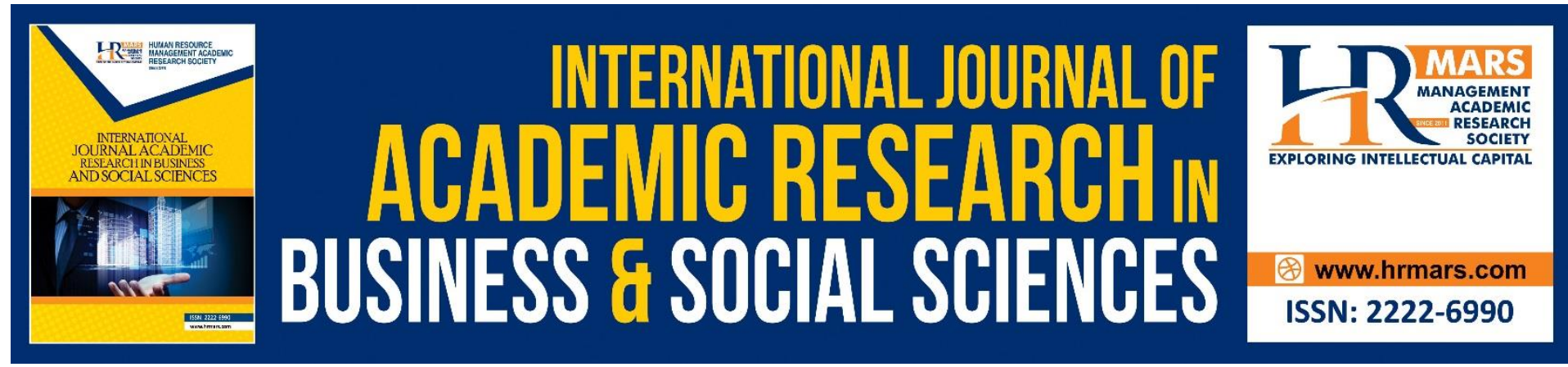

\title{
Wakalah bi al-Istithmar: A Case Study of Wafiyah Investment Account Bank Islam Malaysia Berhad (BIMB)
}

\author{
Marina Abu Bakar ${ }^{1}$ \& Nur Fatin Husna Mohd Nasir ${ }^{2}$ \\ ${ }^{1}$ Kulliyyah of Shariah and Law, Universiti Islam Antarabangsa Sultan Abdul Halim Mu'adzam \\ Shah, 09300, Kuala Ketil, Kedah, ${ }^{2}$ Islamic Business School, Universiti Utara Malaysia, 06010, \\ Sintok, Kedah. \\ Email: marinaabubakar@unishams.edu.my
}

\begin{abstract}
The aim of this paper is to analyse the contract of wakalah bi al-Istithmar, its contemporary applications and Shariah issues involved by taking Wafiyah Investment Account Bank Islam Malaysia Berhad as a case study. The researchers conducted the methodology section using a qualitative method of research. The data was gathered from books, journals, and other secondary-related sources. The data then was analysed using content analysis method. It was discovered that there were two Shariah issues related to wakalah bi al-Istithmar, namely; guaranteed capital and wakalah fee. Consequently, the researchers found that Shariah advisors must closely monitor and review the investment account structure to ensure that no Shariah prohibitions make the contract entailed null and void. For practical purposes, this article stimulated discussion regarding the potential of investment using wakalah bi alIstithmar contract for Sharia advisors, Sharia committees, investors and regulating parties. This article contributes to the body of knowledge regarding wakalah bi al-Istithmar in the Malaysian context.
\end{abstract}

Keywords: Wakalah bi al-Istithmar, Wafiyah Investment Account, Bank Islam Malaysia Berhad

\section{Introduction}

Bank Islam Malaysia Berhad (BIMB) or also known as the Malaysia's first Islamic bank, has a network of channels and the largest Islamic banking, with more than 144 branches across the country. This bank is founded to provide banking and financial solutions based on Sharia principles, which focuses on balancing the needs of the individual and social, and economic activities that promote justice and responsibility to society. Bank Islam offers its retail and commercial customers a range of products and solutions that best suit with their lifestyle, preferences and the business cycle of their business. Wafiyah Investment Account is one of the products offered by BIMB. This investment account was introduced in May 2016 for corporate clients and in September 2016 for retail clients in Malaysia, in conjunction with the execution of the Islamic Financial Services Acts 2013 and 2016 (IFSA, 2013). The holder of an investment account acts as a muwakkil or principal, mandating the Bank to perform 
investment activities on its behalf in order to accomplish the predicted rate of return on investment. This article will discuss the contract involved in the investment of the account, particularly taking Wafiyah Investment Account BIMB as a case study. Apart from that, the concept of wakalah bi al-Istithmar (Investment Agency), its contemporary applications and shariah issues are also reviewed in this article.

\section{Key Features of Wafiyah Investment Account}

1. Investment Strategies for Funds - BIMB has established two strategies for the Wafiyah Investment Account. Firstly, its asset allocation protects the investment portfolio. Secondly, is the bank investing in an existing House \& Fixed Asset Financing and Personal Financing Portfolio with the objective of maintaining a stable profit margin on the financing assets?

2. Minimum Investment Amount - This investment requires a minimum of RM1,000 for one month and RM500 for two months or more.

3. Profit-Sharing Policy - For investors with a tenure of more than 15 months, BIMB will pay the profit based on maturity or on any payment frequency agreed upon by the Bank and the Investor. For instance, BIMB will distribute profits to shareholders on a monthly / quarterly / half-yearly / annual basis. Calculation of returns investment as follows:

Where:

$$
\text { Investment Return }=\frac{\text { Placement Amount } \times \text { Actual Profit Rate } \times \text { Tenure }}{365 *}
$$

Placement Amount $=$ Initial proceeds from IAH

Tenure $=$ Number of days from placement date to maturity date

*Denominator $=$ To follow the market's day-count convention

Example:

\begin{tabular}{|l|l|}
\hline Date of Placement: $1 / 09 / 2018$ & Date of Maturity: 30/09/2018 \\
\hline Investment Amount: RM1,000,000 & Investment Tenure: 1 Month (30 days) \\
\hline Expected Return: $3.50 \%$ p.a. & \\
\hline
\end{tabular}

\section{Valuation of Allocated Asset}

The valuation of allocated asset runs monthly as part of the process to determine the return to IAH. The returns on this investment account will be affected by the performance of the allocated assets including, but not limited to, the quality of assets (i.e. impairment) and movement of Effective Profit Rate (EPR) in relation to financing assets that are priced based on floating rate methods etc. The principal and returns are not guaranteed and an IAH may be exposed to a risk of no returns at all. This investment account is not protected by Perbadanan Insurans Deposit Malaysia (PIDM). However, the product structure was designed to mitigate the risk of losing the principal amount. In the event of a liquidation scenario, the $\mathrm{IAH}$ are ranked ahead of depositors.

\section{Key Risks Involved in Wafiyah Investment Account}

The Bank implements risk management controls over portfolio, legal, and operational activities, including asset allocation, liquidity management, compliance with investment objectives and parameters, valuations, and performance monitoring, in accordance with the 
BNM Policy Document Investment Account. Despite the foregoing, the Bank can safeguard its asset allocation investment portfolio during difficult times, as long as the investments are consistent with the fund's investment objectives. Investors face the following risks:

1. Market Risk - This risk refers to the possibility that price movements (for example, profit rates, foreign exchange rates, or equity prices, as applicable) will have a negative effect on the asset's economic value.

2. Credit Risk - This risk relates to the possibility that the Bank will fail to meet its obligations to IAH on the terms and conditions agreed upon.

3. Liquidity Risk - It refers to potential losses resulting from IAH's liquidity risk, which entails a lower rate of return and the possibility of capital erosion.

4. Operational Risk - It is a term that refers to the potential loss caused by insufficient or failed internal processes, people, and systems, as well as external events.

5. Legal Risk - IAH must ensure that by making this investment, he or she does not violate any applicable laws, regulations, contracts, or other legal restrictions. This investment will be issued in accordance with all applicable laws, regulations, and guidelines. If legislation, regulation, or guidelines change, the Bank may be required to modify some or all of the terms and conditions of these investments, including the possibility of early termination

\section{Terms and Conditions of Wafiyah Investment Account Opening of Account}

There are several steps involved in opening a Wafiyah Investment Account:

1. All applications to open Wafiyah must be submitted in the prescribed format, along with any supporting documents requested by the Bank.

2. Persons who have reached the age of 18 years are eligible to open a Wafiyah account, either individually or jointly.

3. Unless specifically excluded, all requests to open Wafiyah must be accompanied by a completed Investor Suitability Assessment Form.

4. By submitting an application to open Wafiyah, the IAH certifies that he or she has read and comprehended the Wafiyah Product Disclosure Sheet.

5. Wafiyah's acceptance and continuation are entirely at the Bank's discretion. The investment period in which the cheque is used will begin only after the cheque has been explained.

6. By signing the account opening application form ("Products") and/or submitting his / her biometric information to Bank Islam, the Customer acknowledges to appoint Bank Islam as an investment agent to invest IAH funds into an Investment Account in line with shariah contract of wakalah (appointing a representative) considered acceptable by Bank Islam. Profits earned on the investment will be paid in accordance with the Islamic Bank's terms and conditions.

\section{Joint Account}

The following terms and conditions pertain to a joint account:

1. Joint account holders are jointly and severally liable to the Bank;

2. If one of the joint account holders dies or becomes insolvent, the surviving / solvent account holder becomes the trustee for the deceased / insolvent portion of the account balance, and the Bank reserves the right to act in conformance with instructions signed by the surviving / solvent account holder. 
3. If the Bank receives ambiguous or clashing instructions from the joint account holder, the Bank reserves the right to cancel to act in either or both directions or to act in its sole discretion, without incurring any liability to any joint account holder.

4. Any amendment to the requirement entails the joint account holder's signature. Any request to close the account that is signed by all joint account holders will be regarded valid and acceptable by the Bank.

\section{Partnership Account}

Liabilities of joint account holders to the Bank will be joint and several;

1. If one of the partners dies or becomes bankrupt, or the partnership is dissolved for any reason, the balance in the Customer's partnership account will be split in conformance with the partnership agreement (i.e. a partnership agreement on file with the Bank), or if no partnership agreement is entered, the balance in the Customer's partnership account will be divided or distributed in accordance with a court order or other governmental order.

2. Any instructions given for the operation of the partnership account will stay in effect until they are revoked in writing, regardless of the firm's constitution or name, and will apply regardless of changes in firm membership, such as death, bankruptcy, or retirement, or the addition of a new partner.

3. If the Bank receives ambiguous or clashing instructions from the partners and/or authorized signatories of the partnership account, the Bank is free to act as he sees fit or to ignore all commands, without incurring any liability to the partners and/or authorized signatories of the partnership account.

4. Unless all partners agree otherwise, any amendment to the obligation would necessitate their agreement and signature. Any request to close the account that is signed by all partners will be considered legitimate and may be accepted by the Bank.

\section{Authorization}

All dishonoured cheques, banker's cheques, Negotiable Islamic Debt Certificates, bank drafts, postal orders, money orders, warrants, and other instruments shall be returned to the IAH's address last registered with the Bank, at the IAH's risk and expense. If the Bank is negligent, the Bank will not be liable for any unauthorized entries into the IAH's account. The IAH must exercise caution when reviewing account entries and promptly notify the Bank of any errors, discrepancies, irregularities, claims, or unauthorized debits or items made, processed, or paid as a result of fraud, forgery, negligence, lack of authority, or any other act or omission by any person.

Failure of the IAH to notify the Bank in writing within fourteen (14) days of the statement's date of receipt of any error, discrepancy, inaccuracy or claim, debit or unauthorized transaction on the statement (whether accepted or not by the Customer). The statement's record is conclusive evidence that the transaction stated therein was properly carried out, and the IAH has conclusively accepted all matters contained therein as true and correct in all respects. Any disputes regarding transactions brought to the Bank's attention after the fourteen (14) day period will not be considered by the Bank. The Bank will not entertain any disputes regarding transactions brought to the Bank's attention after the said fourteen (14) calendar days. 


\section{Fees and Charges}

No penalty charges will be imposed for any premature redemption. IAH acknowledges that the Bank may implement fees or charges for any of the services appointed to IAH at the Bank's discretion (as approved by National Bank Malaysia) and as disclosed on the Bank's website. The Bank has the right to debit the IAH account for reasons other than those specified in this section.

\section{Investment Redemption and Suspension}

1. The IAH may redeem the investment at maturity at where the IAH can receive the principal investment amount along with the payment of the profit (if any) arising from the investment activities carried out by the Bank.

2. The IAH can reinvest the amount of its principal investment along with the benefits of this investment for the same period as the profit rate is expected as determined by the Bank.

3. IAH can accept less than their initial investment if IAH redeemed all investments before maturity depends on the market value backup / allocated assets where investment is associated at the time of redemption.

4. IAH will receive a lower profit if premature production occurs.

5. Partial redemption before maturity date is no authorized by the Bank.

6. Payment of profit for premature redemption will be using the actual profit rate or the expected profit rate prorated based on actual number complete days, whichever is lower (if any).

7. Notwithstanding the foregoing or any contained in these terms, the Bank shall have the right to suspend any redemption of the Wafiyah under any of the following circumstances or circumstances: -

i. Market failure or financial / economic crisis that includes but is not limited to the stock market crash or asset price fall;

ii. Exceptional operational failure such as wide-scaled black-out or system failure;

iii. Underlying/allocated assets will not be capable of being liquidated at appropriate price

iv. The IAH's interest will be at jeopardy if redemption is not suspended.

v. Any other event or circumstances which the Bank may at its reasonable discretion determine.

\section{Freezing and Closing of Account}

1. Upon receipt of a notice of death, insanity, bankruptcy, or winding up, or upon submission of an order from a court or other appropriate authority or enforcement agency, the Bank may freeze and/or tag the IAH account appropriately.

2. If the Bank suspects the IAH account is being used or is involved in fraud, possible fraud, financial crime, lawbreaker dealings or money laundering, the Bank will send a written notice to IAH (subject to applicable law) requesting IAH to explain and confirm the aforementioned transactions. If the IAH fails to provide a satisfactory explanation to the Bank, the Bank has the right to close, freeze, or otherwise manage the IAH account as it deems appropriate.

3. The Bank may also close / terminate the account in the event of any of the following:

i. The customer is not solvent or in liquidation.

ii. Check deposit is returned or deleted. 
iii. Withdrawal by the Customer all or part of the deposit amount placed.

iv. Customer breaches any of its terms and conditions.

v. The Customer does not accept any changes and amendments to the terms and conditions, and the provisions under Clause 9.2.

vi. Instructions from any law enforcement agencies.

vii. Any other event as the Bank deems fit.

\section{Wakalah Bi Al-Istithmar (Investment Agency) The Definition of Wakalah and Its Permissibility}

Wakalah is derived from the Arabic root word wakala. The word wakala appears in the Qur'an in several places and bears various meanings. These words have different meanings and interpretations, for example, al-hifz (to preserve or to defend), or al-tawfidh (to entrust with or to give mandate) and in terms of agency, it means a person responsible for arranging one's affair. However, all these words are used to indicate "a representation of a person on behalf of another person in certain dispositions" (Al-Bahuti, 1982).

For the technical meanings of wakalah, Islamic jurists of all schools offer various definitions according to their understanding of the notion and effect of wakalah. According to the Hanafi jurists, wakalah is defined as "a representation of another person to act in a permissible (ja'iz) and known (ma'lum) disposition provided that the principal (muwakkil) is legally permitted to do so.". From this definition, it is understood that there are two main important aspects of wakalah. The two aspects are the disposition must be "permissible" and "known". By "permissible disposition", it is made clear that any unlawful acts shall be discarded. Therefore, it is not allowed for a minor to authorize someone to distribute gifts (hibah) from his property. It is known that a child is prohibited to act in any harmful dispositions, whether it be verbal disposition (tasarruf qauli) or actual disposition (tasarruf fi'li). The disposition also must be known. Any unidentified or ambiguous disposition (tasarruf majhul) is excluded.

The Maliki jurists define wakalah as "a representation of one person (wakil) by another person (muwakkil) to dispose over his rights and possessions without restricting a deputation after his death". The definition specifies the elements of wakalah that excludes a testament (wasiyyah). So, according to Maliki jurists, wasiyyah is not wakalah. According to the Shafi'i jurists, wakalah is defined as "the authorization of one person (wakil) by another person (muawakkil) to dispose of something (muwakkal fih) during his lifetime provided that he (muwakkil) has the right to do so and that such things are liable to be represented". The definition provides that the representation should exist during the principal's lifetime. This is to distinguish wakalah from testament (wasiyyah). Somehow, this definition is also similar to Maliki's jurists.

The Hanbali jurists propose the definition of wakalah as "a deputation of a person who is legally competent (muwakkil) by a person of the same qualification (wakil) in matters embodied under the concept of deputation". This definition mentions the main elements of wakalah and those are the principal and the agent and requires that they must be legally competent in order to engage in agency contracts. In addition, the definition also names the subject matter of agency which is reflected in the rights of Allah SWT, for example implementing punishment for crimes (hudud) and the rights of man for example in transactions (mua'malah). 
Muslim jurists unanimously agree that the practice of wakalah is permissible and lawful. Wakalah derives its legality from the Qur'an, Sunnah and consensus of Muslim jurists (ijma'). There is no single verse that directly testifies the permissibility of wakalah. However, there are a few versus of Qur'an that are significant and referred by Muslim jurists as the permissibility of wakalah. Allah says in the Qur'an:

"...Now send ye then one of you with this money of yours to the town, and let him find out which is the best food (to be had) and bring some to you, that (ye may) satisfy your hunger herewith...".

This verse is related to the Companions of the Cave (Ashab al-Kahf), which one of them was appointed to go out and buy food from the city with their silver coin. In this verse, the word ib'athii could mean "send" or "appoint" or "authorise". Even though, the verse tells the story of the people in the past, but the injunction is still valid and relevant. Al- Jaziri mentions that Allah SWT and His Messenger (PBUH) justify and approve this type of transaction among people since no abrogation is made to the verse (shar'u man qablana shar'un lana ma lam yarid al-nasakh). Ibn Arabi stipulated that this is the most authoritative verse which justifies the legality of at wakalah as wakalah is a contract of deputation permitted by Allah SWT to answer human needs, since a person is unable to fulfil all of his needs except by the assistance of others.

There are various Prophetic traditions (his deeds, sayings and tacit approval) that recognise and approve the legality of the practice of wakalah. Prophet Muhammad (PBUH) himself was directly or indirectly involved in such transactions. One of the important hadith which is reported is that Jabir bin 'Abdillah was addressed by the Prophet Muhammad (PBUH) when he intended to go to Khaybar as follows: "If you meet my agent, take or ask from him fifteen wasq" (a type of measurement). This hadith reported by Abu Dawud, Al Baihaqi, al- Dar Qutni and al-San'ani. The hadith explicitly justifies the legitimacy of wakalah. It is also known that the Prophet Muhammad (PBUH) appointed his agents in many places for different purposes. It was also narrated that the Prophet sent his assistants (su'at) to collect alms (zakat). Some writers also quoted the hadith as narrated by Abu Hurairah, claiming that the Prophet Muhammad (PBUH) sent 'Umar for the purpose of collecting zakah. Another hadith narrated by 'Urwah al-Bariki who said that Prophet Muhammad (pbuh) had given him one dinar to purchase sacrificial sheep for the Prophet. In these cases, the Prophets assistants acted in the form of wakalah.

Most of the jurists agree upon the permissibility of the practice of wakalah. In respect of ijma', Muslim jurists were unanimously agreed that the contract of wakalah is permissible. The need to employ an agent to perform a certain task which the principal has neither the time, knowledge nor expertise to perform himself, confirms the legality of at wakalah. The importance of wakalah is illustrated by the concept of co-operation or mutual relationship between each and every individual in society. An agent may act in some activities on behalf of his principal in the situation where the principal does not perform the task by himself, either because he cannot, or because he chooses to find somebody else more capable in skill and experience than himself, or for some other reasons. The concept of co-operation in society and its existence in various types of action are undoubtedly very much encouraged in Islam (Fuqani, 2013). 


\section{Wakalah - Integral Parts (Arkan) and Its Key Types}

The contract of agency is formed by a number of constituent elements (arkan) without which the contract will not come into existence. The essential elements of wakalah following the classification of the majority of the jurists are the formation (sighah), the principal (muwakkil), the agent (wakil) and the subject matter (muwakkal bihi).

\section{i) The Formation (Sighah)}

Sighah is necessary to ascertain if the two contracting parties truly intend to establish an agency relationship. It is important to consider the parties' stated intentions or fundamental objectives, instead of any hidden ones. The approval of the two contracting parties is the key factor in the contract's conclusion. As a result, without the sighah, the contract will not be formed because the intention and approval will remain hidden. Like other contracts, the parties must consent free from duress, fraud, misrepresentation, or mistake. Formation (sighah) is a verbal expression comprised of two primary components: offer (ijab) and acceptance (qabul). Both are typically completed concurrently with the contracting parties' meeting (majils al-'aqd).

An offer refers to an initial statement made in first place by one of the two contracting parties raising the subject between the parties. An acceptance on the other hand, is the statement made in the second place by another party who completes the contracts. The offer and acceptance must be clear for the contract to be valid. As with the offer, the acceptance can be expressed either by verbal expression or by other means of expression. For instance, some of the verbal acceptances are as follows; "I accept the agency" or "I will perform your order" or "I will represent you" and other similar expressions. These expressions are clear and do not bear another meaning.

\section{ii) The Principal (Muwakkil)}

The principal is the contractual party in the agency relationship for whom someone else is asked to act as his representative. The principal should possess legal capacity to enter into a contract. In other words, he must be able to perform the act which is the subject matter of the contract. Therefore, an insane or minor can't enter into a contract of wakalah. However, according to Hanafi jurists, a discerning minor may appoint an agent to perform acts which can cause a loss for that minor.

The Majelle stated that "the principal must be able to perform the act which is the subject matter of the agency". In other words, he must be legally competent. That competency can be described as the criterion that the principal must fulfil in order to validate the contract of agency. Only if he is legally competent, can the principal validate the contract of agency. Also, for the validity of the formation of the contract, the parties entering contractual obligations must be able to reason clearly and understand the nature of the acts. But if for some reason a person becomes incapable of exercising his legal rights, then he is called an interdicted person (mahjur). The requested criteria and important instances of interdiction are mental capability or sound mind ('aql), puberty (bulugh), prudence (rushd), bankruptcy (iflas), death sickness (mard al-maut), and duress (ikrah). 


\section{iii) The Agent (Wakil)}

An agent is a person who has the power to affect the legal position of another person (the principal). Thus, the agent should possess the capacity of execution and understand the nature of the transaction that he conducts on behalf of the principal. The agent of wakalah contract should possess the full capacity of execution that requires sanity and ability of understanding and discrimination. Wakalah, in order to be accepted, the agent must be sane ('aqil). The agent should have legal capacity (Al-Ahliyyah al-Kamilah). Thus, a lunatic or and indiscriminating minor (sabbiy ghair mummayyaz) can't be appointed as an agent. However, according to the Hanafi jurists it is not allowed for sabbiy mummayyiz to carry out the contract of wakalah (Ibn Rushd, 2004).

\section{iv) The Subject Matter (Muwakkal bihi)}

The subject matter of wakalah contract is the action in the contract of which the agent is appointed. Agency is permissible in Shariah; thus, it is not permissible to delegate someone to perform unknown activities (Al-Shirazi, 1995). If the contract aims to purchase a commodity, the genuineness, kind, quality and other necessary attributes of the commodity to be bought should be mentioned (Al-Sharqawi, 1997). In addition, the agency must be a lawful action and could be disposed through wakalah (Ibn Rushd, 2004). Agency is not permissible for prohibited acts by Shariah or acts of disobedience such as theft, usurpation of property or conducting riba'-based business. AAOIFI Shariah Standard also specifies that the subject matter of wakalah shouldn't involve a non Shariah compliance practice, like trading in impermissible commodities or committing usurious lending (AAOFI Shariah Standard, 2008).

\section{Types of Wakalah}

The wakalah contract is categorized according to its subject matter or refers to the limit of an agent's authority or, in some cases, to the criterion established by the principal to be fulfilled by the agent.

i) General Agency (Al-Wakalah Al-'Ammah) and Specific Agency (Al-Wakalah AlKhassah)

A general agency refers to a general delegation of power. For example, if the principal says: "I delegate to you all my affairs". In this case, the principal has transferred and delegated the power to the agent. The exemption of the delegated power covers harmful things to the principal like giving a gift (hibah) or divorce. Thereby, the agent has no authority to divorce the principal's wife unless the principal specifically mentions it in the contract AAOIFI Shariah Standard specifies that general agency includes all method of disposing of assets provided that the interest of the principal and the customary practices are well observed.

On the other hand, a specific agency is made only for a certain known transaction. If the agent has been appointed for a particular disposition, he is under an obligation to dispose within the scope of that particular disposition. It is not allowed for the agent to exceed the limits determined by the principal. For example, buying or selling a known house or a specific car. The agent is bound to sell or buy that particular house or car only (Ibn Rushd, 2004). 
ii) Restricted Agency (Al-Wakalah Al-Muqayyadah) and Absolute Agency (AlWakalah Al-Mutlaqah)

Restricted agency is where the agent has to act within certain restrictions or boundaries either in the form of requirements, conditions and characteristics relating to the nature of the disposition to be taken by the agent. These conditions have to be strictly observed if not the transaction is not binding on the principal. For example, the owner says: "I appoint you as my agent to buy a house at such price or until such time or based on installments". The agent in this case has to strictly observe these conditions. If any of the conditions is not met, the transaction is not binding on the principal (Ibn Muflih, 1997).

In contrast, there is no condition or restriction put for the transaction in absolute agency. Nevertheless, according to Imam Muhammad and Abu Yusuf of the Hanafi school, Maliki's, Shafi'is and Hanbali's, an agent is still bound to act within the prevailing practices and customs. The agent though has unlimited authority and must uphold the interest of the principal since the authority is awarded by the principal. For example, the principal says to his agent: "I delegate you to buy a land.", without mentioning specific price or type. In this case, according to the majority of jurists, Imam Muhammad and Abu Yusuf, the agent has the authority to buy any land within the prevailing practices and customs. However, Imam Abu Hanifah argues that an agent is not bound by the customs as customs differ from one place to another (Ibn Nujaym, 1997). An unlimited authority should be treated in its absolute form and the agent can perform freely.

AAOIFI Shariah Standard states that the agent is bound by the customary practices and must act in the best interest of the principal. He is not allowed to sell at less or buy at more than the market price except with the prior consent of the principal (AAOFI Shariah Standard, 2008).

iii) Provisional Agency (Al-Wakalah Al-Mu'aqqatah) and Non-Provisional Agency (Al-Wakalah Ghair Al-Mu'aqqatah)

Provisional agency is terminated after a specific duration. In this regard, the agent can't act or perform any transaction on behalf of the principal after the expiration of the period. For example, where the principal appoints an agent for a certain time, the agent can't act or perform any agency transaction beyond that time limit. However, there is no particular timelimit imposed on non-provisional agency. In this situation, the contract is terminated when the subject matter of wakalah is completed by the agent. For example, if an agent is empowered to sell goods without the restriction of any particular duration, his authority is valid until the goods are sold. In this case, the duration may be long or short. The jurists say nothing on the reasonable duration; therefore, it may be assumed that this is according to trade custom ('urf). The agent may withdraw from the agency contract when he finds himself unable to perform the agency for whatever reason, provided that he informs the principal first. The principal can also terminate his agent's authority for whatever reason, provided that the agent is made aware that his authority as agent has been terminated. The knowledge of the agent and the principal is important in order to avoid any problems or complications.

\section{Right and Obligation of the Contracts Executed by the Agent}

The general principle of the law of agency states that, when an agent is authorized by a principal to enter into a contract on the principal's behalf, and he does so, the contract is 
created. It is first necessary therefore to show that the contractual relationship of principal and agent has arisen; and this generally depends on the agreement between the principal and the agent. This unique relationship bestows the agent with certain rights against his principal and binds him to certain obligations toward that principal.

There are two sets of contractual relationships in any agency contract. First, the relationship which exists between the principal and the agent. This bilateral relationship is similar to many other contracts where the rights and duties of the parties inter se are regulated by the express and implied terms of the contract. Second is the relationship between the principal and a third party. This relationship occurs when the agent withdraws from the transaction after he has negotiated the contract between the principal and the third party. Muslim jurists did not distinguish between these two types of relationships.

\section{Duties of the Agent}

Once the relationship of principal and agent is established, a number of duties are imposed upon the agent. These duties are specified in the contract and are equitable in character. Agency relationships normally arise from an agreement, particularly a contract, which comprises express or implied terms. The terms govern the rights, duties and liabilities of the parties. Besides those duties, there are others which stem from the fact that the agency relationship is a position of trust. In other words, the rights and duties of the agent may derive either from an agreement into which they have entered or simply from the fiduciary nature of their relationship. The duties of the agent are discussed as below:

1. The Duty to Carry Out the Work with Ordinary Skill and Diligence.

The most important duty of agent is to fulfil the agency itself. In other words, he is under a contractual duty to perform what he has undertaken to perform and must personally fulfil his obligations with reasonable care, discretion and diligence according to the terms of his contract and the instructions of his principal.

2. There Must Be No Conflict of Interest between the Agent and the Principal.

The general idea is that the agent must not let his own personal interest conflict with the obligations he owes to his principal. The agent must perform his duties in accordance with the interest of the principal and act in a way which ensures a benefit to the principal. Therefore, the agent must not misuse his position for his personal benefit and to the detriment of his principal. In other words, the agent should not be led into temptation where he has to balance his own interests against those of the principal. That the duty should not to be in conflict with the interest of the principal is really related to the principle of trust.

3. Duties to Keep Proper Accounts of All Transactions Connected with the Agency and Render Them to the Principal on Request It.

It is ordinary practice for the principal to supervise or control the performance of the agent. Therefore, the principal may ask the agent to produce an account of all transactions. The agent must upon request inform the principal about the stage he has reached in performing the agency and must give him a clear account after its completion. 
4. The Duty Not to Accept Bribes or Secret Profit.

The duty not to accept bribes or secret profit is highly appreciated in Islam because it is associated with moral conduct and value. Islam prohibits both offering and accepting bribes as well as making a secret profit. Bribery is to be offered or promised to be offered to someone in order to influence him or persuade him to do something wrong in favor of the giver.

5. Trust (Amanah).

A concept of trust is very highly appreciated in Islam. A trustworthy or trustee (amin) is a person who possesses good characteristics such as integrity, honesty, sincerity and faith in God. If amin is entrusted with property to look after, he is bound to keep that property sale as he would look alter and protect his own. Broadly, the duty of the trustee is to guard the interest of the person on whose behalf he holds the trust and to render back when required according to the terms of the trust.

The agent is in a fiduciary relationship (a position of trust) with his principal and must therefore always act in a way which justifies the principal's confidence in him. He is engaged to look alter his principal's interest and must not seek additional profit for himself out of his position beyond the commission or other remuneration allowed to him by the principal. Accordingly, everything held and gained by the agent during the period of the agency relationship is in a form of trust or consignment. For this reason, the jurists said that the agent will not be liable for compensation (dhaman) if the subject matter is destroyed or perished in his hands unless the destruction is caused by his negligence and delinquency.

6. The Duty Not to Take Advantage of His Position or His Principal's Properly in order to Acquire a Benefit for Himself.

An agent cannot utilize the property of the principal without the permission of the principal nor any confidential information which he has acquired in the course of his employment as agent. Unless he has permission from the principal, he must not take advantage of and make use of such property for his own benefit. An example would be the case of an agent who has been entrusted with goods for sale, used the goods for his own interests or hired them to another person without the consent of the principal.

\section{The Rights of the Agents Against his Principal}

Beside the duties the agent owes to the principal, he also has several rights. Normally, Muslim jurists discuss this matter along with other general obligations of the contract of agency. The most important rights are the right to be remunerated for the service rendered, the right to be reimbursed and indemnified and the right for lien.

\section{The Right to Be Remunerated for the Service Rendered.}

In agency relationships, an agent may act with or without being remunerated. In the case where he acts voluntarily, it is considered that he acts out of courtesy or kindness to his principal. Both types of agency are permissible and their proof of legitimacy is based on the deeds of the Prophet (PBUH) where he is reported to authorize agents for several purposes with and without remuneration. For example, the Prophet (PBUH) authorized agents to collect zakat and he gave them wages (Al-Zuhayli, 2003). In addition, the contract of agency is a possible contract ('aqd jaiz) in the sense that it is not compulsory for the agent to perform 
the subject matter of the agency. So, in the case where the agent performs the duty, he may accept the remuneration or any relevant commission for his service (Al-Zuhayli, 2003).

The main duty of the principal towards the agent is to pay the agent the agreed commission for the services rendered. Where there is an express or implied agreement to pay it, the agent can claim remuneration. The right to be remunerated, both the amount of the commissions as well as the circumstances in which it becomes payable, stems from the contract. Accordingly, the jurists predominantly agreed that the agent will not be entitled to receive a commission unless there is an express or implied term in the contract or implied term in the contract of agency providing for his remuneration. If no stipulation has been made for payment in the contract, and the agent is not one of those persons who work for a wage, his service is considered free and he can't ask for payment. Corresponding to this point, the Hanafi jurists justify that if the agent works in a profession which is known to be paid for the service such as solicitor, he is entitled to claim remuneration. It is also necessary to point out that the agent can only claim his remuneration when he has completed the agreed job. If he withdraws or relinquishes his agency without completing his duty, no commission has to be paid by the principal. The jurists considered the agent with remuneration as equivalent to the contract of hire especially concerning the right of payment.

2. The Right to be Reimbursed and Indemnified

Every agent has a right to be reimbursed all expenses and indemnified against all losses and liabilities incurred by him whilst acting within the scope of the agency. In performing the agency, the agent might need to spend some of his own money. In this case the agent is entitled to seek indemnification from the principal even though there is no clause referring to it in the contract. It normally stems from the nature of employment or practice of custom ('urf). All expenses made in the course of agency are considered within the limit of agency. The principal should not refuse to reimburse upon request by the agent.

\section{The Agent's Lien}

A lien is a right to keep possession and refuse to hand over to the owner. Generally, the jurists are not in agreement on this question. According to one of the Hanafi jurists, an agent who is entitled to claim an indemnity and remuneration from the principal may also exercise a lien on any properties belonging to the principal which is in the agent's lawful possession as an agent until the claim is met. The agent may do so even though there is no provision for lien.

\section{Appointment of a Sub-Agent}

The basic principle underlined that an agent can only act in his principal's interest and is not authorized to appoint a sub-agent. However, there is an exception to this principle when this is impossible or when there are difficulties in an agent performing his duties alone. There are numerous opinions regarding the permissibility of an agent appointing another person to be his agent. According to Hanafi, it is allowed for general and absolute wakil to appoint someone else to be his agent (Ibn Nujaym, 1997). Maliki jurists uphold the view that it is not allowed for wakil to appoint anyone as wakil, except if that wakalah (delegation) is not suitable for his personality. Shafi'i and Hanbali jurists are of opinion that it is not allowed for wakil to delegate another person without consent of principal (wakil) as far as he is capable of carrying out what he has been delegated for, though, if he is not capable of carrying out all 
what muwakkil appointed him for. In this case, it is allowed for him to appoint someone else as agent (Ibn Qudamah, 2004).

Hence, this is confirmed by AAOIFI Shariah Standard which specifies that the agent has no right to appoint a sub-agent except with the permission of the principal (AAOFI Shariah Standard, 2008). Several exceptions to this general rule have been specified by the jurists as follows (Al-Zuhayali, W., 1989).

i. If the task is not appropriate for the social status of the commissioned agent whom is a nobleman. For example, selling livestock in the market.

ii. If the commissioned tasks are numerous, and can't all be accomplished by the agent without help.

iii. If the task requires specific skills that are not possessed by the agent, for example in designing and building a bridge.

Once a sub-agent is appointed, his termination doesn't spontaneously follow the termination of the first agent, but depends on the principal, whether to terminate his appointment or not.

\section{Termination of Wakalah}

There are many different ways in which wakalah could be ended:

i. Wakalah contract could be ended by mutual agreement.

ii. If the subject matter of the wakalah has been conducted and has achieved its purpose.

iii. Resignation of wakil; wakalah could be ended by resignation of wakil. However, the Hanafi jurists stipulated that the agent has to inform the principal, while Shafi'i jurists differ.

iv. If principal (muwakkil) terminates his wakil (agent): the principal has the authority to remove agent at any time he/she likes. However, according to Hanafi, two conditions must be fulfilled namely: (1) The principal must inform and notify his agent. However, others like Shafi'i and Hanbali are on the opinion that notification of agent is not a condition. (2) The agency contract does not interfere with other person's right, for instance, if principal appoints someone to divorce his wife anytime, he likes, thus the husband or principal has no right to revoke the agency without the consent of the wife.

v. If either wakil or muwakkil possesses limited capacity. e.g. he/she becomes insane, or in the inevitability of death. Also, he/she has legal interdiction (al-hajr).

vi. Destruction of the subject matter e.g. by selling or buying or hiring it.

\section{Contemporary Applications of Wakalah}

Wakalah contract is used by Islamic Financial Institutions in respect of many Islamic modern financial products like mudharabah, salam, istisna', ijarah, musharakah mutanaqisah and activities like the letter of credit, payment and collection of bills, fund management and securitization (Hasan, 2011). Islamic banks usually don't pay any fees to their customers who sell or purchase goods on their behalf. The fees will be charged only if the banks act as an agent to perform certain acts on behalf of their customers. Examples of the application of agency contract in Islamic banking: 
i) Deposit takings based on wakalah

This deposit product is based on Shariah principle of wakalah. It refers to a contract between two parties, i.e the owner of the capital (muwakkil) and the bank (wakil). The banks can manage funds of investors on the basis of wakalah bi al-Istithmar i.e agency services for the management of the funds. The banks usually can get pre-agreed fee irrespective of the profit or loss on the relevant portfolio. This fee may be fixed in a lump sum or as a monthly or annual remuneration in percentage of the amount of investment or the net asset value of the fund. The above method needs to be determined before the launch of the fund (Ayub, 2002).

Bank Negara Malaysia's Shariah Advisory Council has determined that the use of wakalah bi al-Istithmar contracts in deposit accounts is permissible. However, such contracts must be implemented prudently to avoid the agent providing a guarantee on the investment returns (Bank Negara Malaysia, 2020). Figure 1. 1 below is the modus operandi for deposit takings based on wakalah:

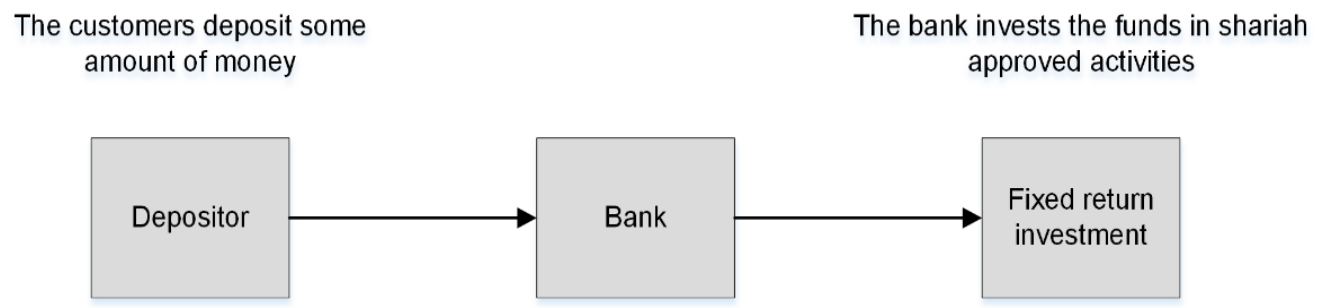

Bank works as an agent to invest the money in specified investment portfolio

Figure 1.1: Deposit Takings Based on Wakalah

i. The investor, who is the owner of the capital, places a specified sum of money with the Bank;

ii. The Bank which acts as the wakil in this contract, will invest in contract, will invest the funds in specific investment activities of the Bank with the objective of making profits.

ii) Letter of Credit (LC) based on wakalah

A letter of credit (LC) is a written undertaking given by the bank to a seller or exporter to the effect that the bank will pay the seller a certain of amount stipulated in the LC, provided that the seller complies with the term and conditions of the LC.

Under the contract of wakalah, the customer asks the bank to issue LC for a fee. In this context, the bank will act as an agent of the customer as the customer pays the full purchase price to the supplier. Figure 1.2 below is the modus operandi for Letter of Credit (LC) based on wakalah: 


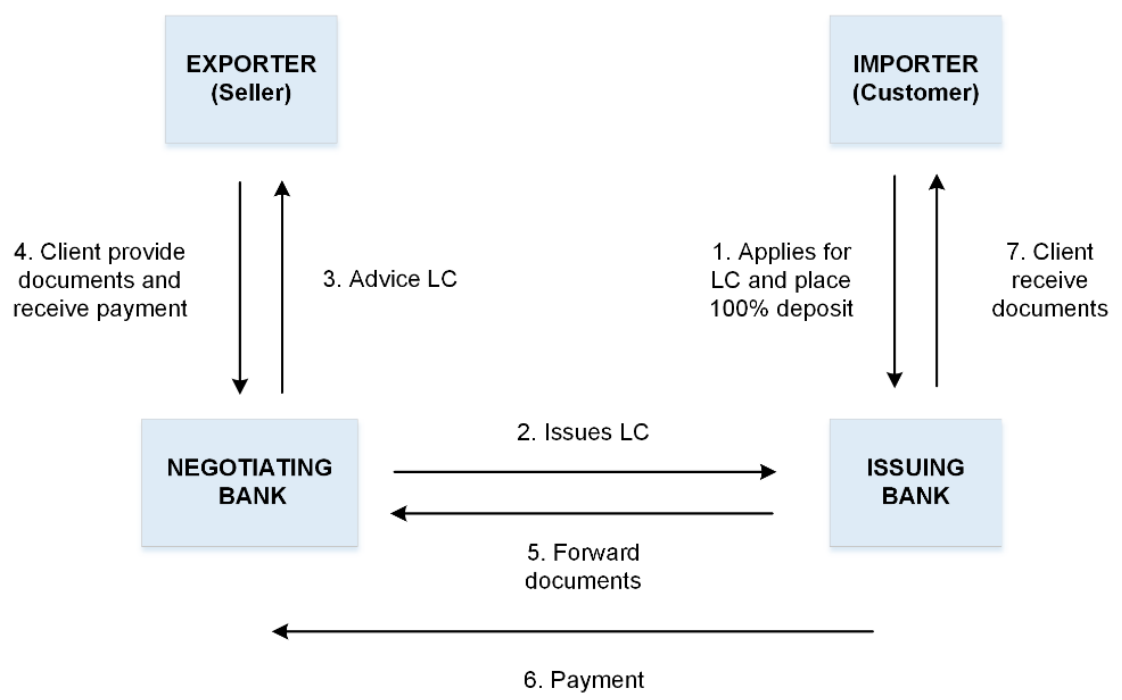

Figure 1.2: Letter of Credit (LC) based on Wakalah

The customer informs the bank of his LC requirements and requests the bank to provide the facility.

1. The bank may require the customer to place a deposit to the full amount of the price of the goods to be purchased or imported which the bank accepts under the principle of wadi'ah yad dhamanah.

2. The bank establishes the LC and pays the proceeds to the negotiating banks, utilizing the customer's deposit, and subsequently releases the documents to the customer.

3. The bank charges the customer fees and commissions for its services under the principle of ujr (fee).

iii) Private banking investment

This contract is customized to suit the needs, financial expectation and investment goals of an individual client. In this contract, the bank will receive a deposit of investment goals of an individual client. The fund collected will be invested in the list of authorized investment, including money market instruments, Islamic securities, unit trust and others.

The proposed portfolio will be an integration of debt and equity-invested mechanism to ensure portfolio flexibility and protection. In consideration of the services provided by the bank, the client will pay some fees. These paid-fees could be construed on numerous Islamic contracts; among others is the contract of wakalah. In this situation, the bank will be considered as an agent to the customer to work with the money and is paid a sum of money for providing the services to the client. As an agent, the bank is indemnified against losses as a result of any transaction entered into in the course of managing and investing the fund, except in the case of negligence.

\section{iv) In Tawarruq Financing}

Tawarruq is defined by the Fiqh Academy as buying a commodity from a seller who possesses it at a deferred price, and then the buyer sells the commodity to a third person, in order to obtain liquidity. According to a majority of the scholars, tawarruq is legally permissible, based on that the origin of things is permissibility and Allah says, "Allah has allowed trade and has prohibited riba". Furthermore, the Shariah Advisory Council of Bank Negara Malaysia has also resolved that financing based on the concept of tawarruq is permissible. Usually, the contract 
of tawarruq is supported with the agency contract. In practice, the customers normally enter into the contract of agency and appoint the bank as their agent to sell the commodity to a third party.

In fact, the appointment of the bank as the client's agent to sell back the commodity to the market is not a matter of consensus among modern jurists. Whilst, some jurists believe that the appointment of anybody (including the bank) to sell the commodity back to the market wouldn't affect the validity of tawarruq, some jurists believe that the appointment of the bank as an agent shows that the intention of the client is not to own the commodity, but to only use the commodity as the conduit to get cash. Hence, they propose that there shall be no appointment of the bank as the client's agent to sell the commodity back to the market.

The AAOIFI, on the other hand, take the middle path, whilst regulating that there shall be no appointment of the bank to sell back the commodity, it does consider the situation where the client is not allowed to sell the commodity on his own. Hence, it states: "the client shouldn't delegate the institution or its agent to sell, on his behalf, a commodity that he purchased from the same institution and, similarly, the institution shouldn't accept such delegation. If, however, the regulations don't permit the client to sell the commodity except through the same institution, he may delegate the institution to do so after he actually or impliedly, receives the commodity".

The Standard further states that the "the institution should not arrange proxy of a third party to sell, on behalf of the client, the commodity that the client purchased from the institution. The client also shouldn't sell the commodity except by himself or through an agent other than the institution, and should duly observe the other stipulations".

With respect to financing mechanism based on tawarruq, the sequence of the transactions would be as follow as in Figure 1.3:

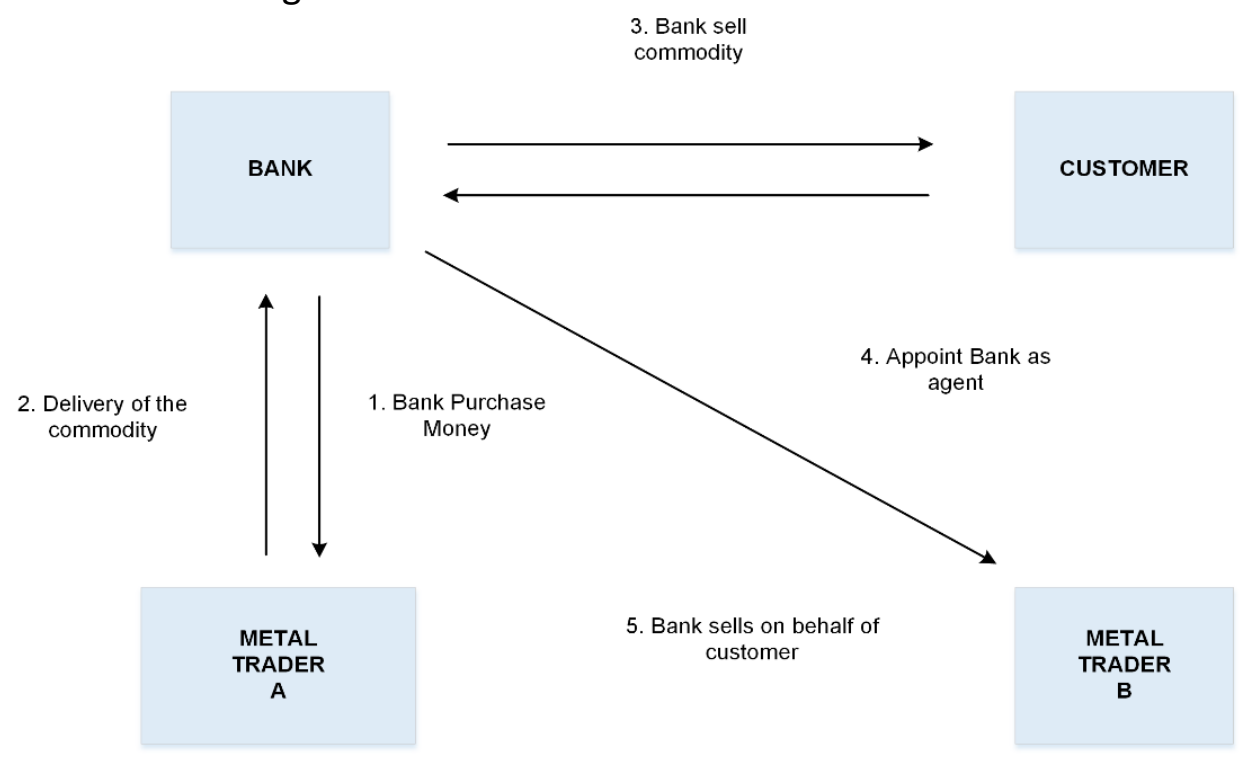

Figure 1.3: Tawarruq Financing using Wakalah 
i. The bank purchases the metal commodity from metal trader A on cash basis;

ii. Thereafter, the bank sells the metal commodity to the customer on deferred price (cost price + profit margin).

iii. The customer may appoint the bank as his agent to sell the metal commodity to a metal trader $B$ on cash basis in the metal commodity market. The cash sale price by the customer to metal trader $B$ enables the customer to obtain cash for financing, while the deferred sale price from the bank to the customer enables customer to pay back the financing facility to the bank within an agreed term.

\section{v) Al-Wakalah in Takaful}

Wakalah is one of the Shariah contracts that can be used in takaful. The agency model in takaful describes an agency agreement or relationship between the operators, acting as the agent or wakil to the participant as a principal to manage his/her participation of takaful products provided by the operator. In return, for giving the agency services, the operator through the agent is permitted to change a wakalah fee.

The fee is payable from the takaful contribution paid by the participant. In this model, management expenditure can be charged to the takaful fund as upfront charges. The operator also earns it revenue from the agency fee described in the aforementioned as well as returns on the investment of its shareholder's fund. However, there are also operators practicing the model charge performance fees for the roles and services in managing the investment of the takaful fund. In the event of a cancelation or surrender, the participant will be refunded of the net balance of his contribution, if any, after deducting all the upfront charges such as the wakalah fees and other management expenses from the takaful fund.

Figure 1.4 below illustrates the model of general takaful using wakalah. Under the wakalah model for general takaful, participants as a group appoint and authorize the takaful operator to be their agent (wakil) to manage the takaful fund. The takaful operator will be participants' agent (wakil) for both the takaful and above the original wakalah fee, this is considered as a pure wakalah model. However, if the takaful operator charges an additional "performance fee" as a percentage of the net underwriting surplus, this is considered as modified wakalah model. Furthermore, under the modified wakalah model, the participants contribute to be general takaful fund under by way of donation or tabarru'. The participants then appoint the takaful operator to be their agents (wakil) to manage their takaful and investment activities of the takaful fund. The operator is remunerated with an up-front wakalah fee. All the investment profits are channeled back into the takaful fund. At the same time, the takaful fund is used to pay claims and other expenses such as, the re-takaful and reserves. The net surplus is to be returned to the participants after deducting an agreed percentage as "performance fee" for the takaful operator (Abdul Aziz, 2013). 


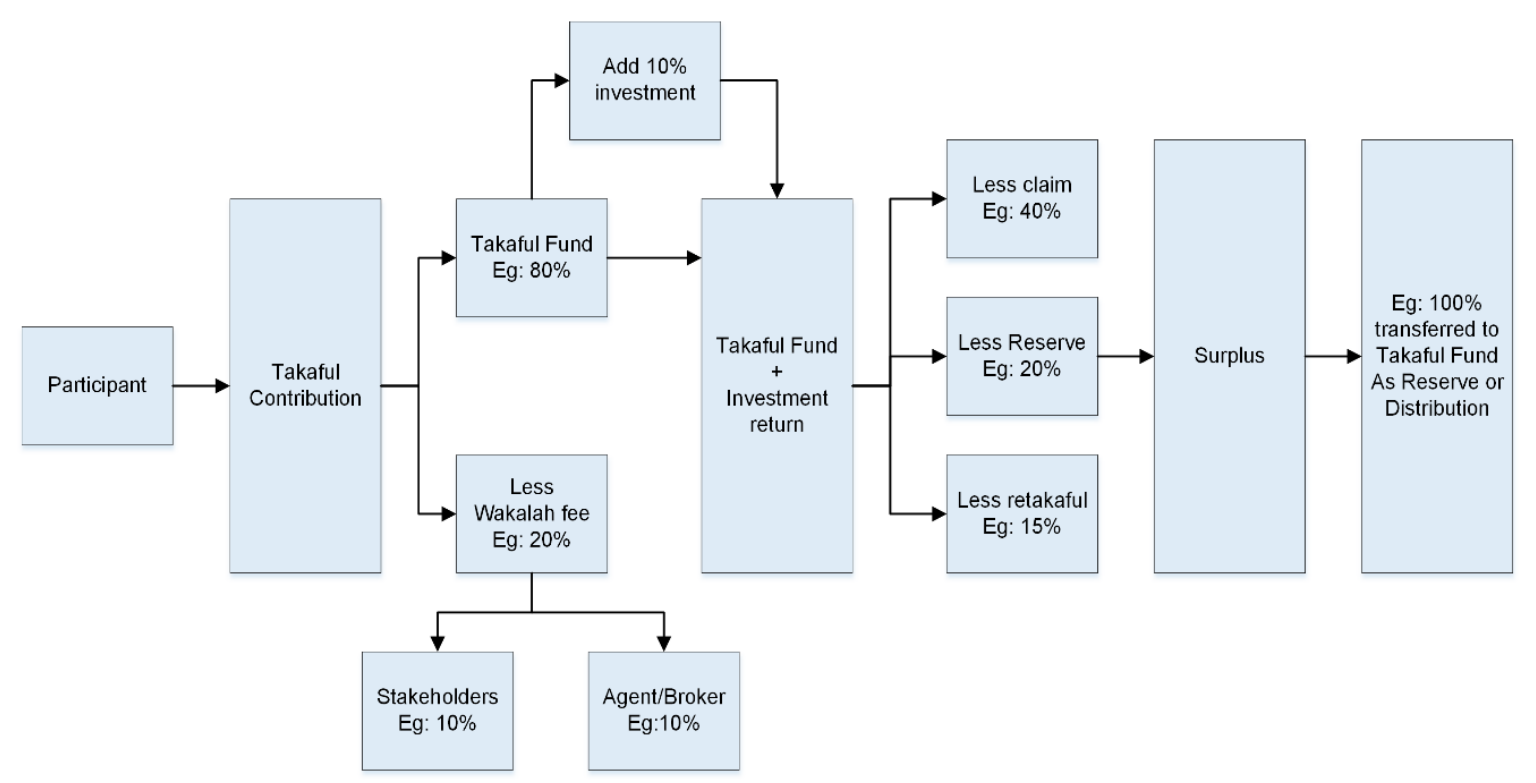

Figure 1.4: General Takaful- Wakalah Model

\section{BNM Guidelines on Wakalah And Investment Account}

Basically, there are four conditions pertaining to the basis of wakalah contract outlined by the Bank Negara of Malaysia (Bank Negara Malaysia, 2015). The conditions are as follow:

1. The muwakkil shall authorize a specific wakil and notify him of his appointment.

2. The Bank act as an agent (wakil) to perform a particular task, in matters that may be delegated, either voluntarily or with imposition of a fee.

3. Subject matter in wakalah contract should be known to agent and it is not permissible to delegate someone to perform unknown thing.

4. Offer and acceptance may be expressed verbally or by appropriate documentation or by any other methods accepted by customary business practice which does not contravene the Shariah principles.

Wakalah is an agency contract in which a party mandates another party as his agent to perform a particular task. In the current context of Islamic finance, the customer normally appoints a financial institution as his agent to conduct a particular mu amalah transaction and in return, the financial institution will receive a fee for the service.

An Islamic financial institution would like to introduce a deposit product based on wakalah bi al-Istithmar (investment agency). Under this product, a customer will deposit a certain amount of money at the Islamic financial institution with the condition that such deposit shall only be invested in an instrument with the potential to generate return at a certain minimum rate (for instance 5\% per annum). The Islamic financial institution will act as an agent in investing the customer's deposit and will be entitled to a fee as agreed by both parties.

However, the Islamic financial institution will not guarantee that the customer will be getting at least the minimum investment profit rate as expected. Any loss will solely be borne by the customer unless it is proven that the Islamic financial institution had been negligent or had breached the terms of agreement by investing in an instrument which has no potential to generate the minimum profit of $5 \%$ per annum. In addition, if the customer decides to 
terminate the investment contract earlier and withdraw all of his deposit, he is only entitled to receive the current value of the investment. In this regard, the SAC was referred to on the issue as to whether the proposed deposit product which is based on wakalah bi al-Istithmar is permissible.

\section{AAOIFI Standards on Wakalah And Investment Account in Amount, Term And Profit Of The Investment}

The amount and term of the investment should be determined, regardless of whether the amount is paid as a lump sum or in installments. The principal is responsible for all expenses related to investment such as transportation, storage, taxes, maintenance and insurance. It is not permissible for the agent to pay them from the agent's own funds, or to postpone the repayment due to the agent for which he has paid in the principal's behalf or to make such replacement subject to investment. And the investment agent is responsible, as a legal entity, for any related expenses to its employees or equipment. An agent may initiate investment activities before receiving funds (from the principal), and with the principal's consent, by:

a) Incurring a debt on behalf of the principal by buying on credit;

b) Advancing a loan to the principal to buy something on his behalf.

Any loan developed by an agent is interpreted as a non-interest loan that may not have the benefit of the agent as a creditor. The agent is entitled to a fee and performance incentive, irrespective of the loan developed. The total benefit is the principal right unless it is determined that the agent is entitled to all or part of any advantage over the expected profit as a performance incentive in addition to his fixed fee. Agents are permissible, with the consent of the principal, to set aside part of the profits to make a profit equalization reserve for the benefit of the principal. After the liquidation, the balance of the profit equity allocation reserve is returned to the principal without affecting the agent's right to fixed fee or performance incentives for a period in which savings set aside.

\section{Fatwa Dallah Al-Barakah on Wakalah Bi Al-Istithmar}

(8/4) Investment through an Agent for a Specific Fee:

It is permissible to give money to a person who has worked on a specific task by allocating a specific amount of profit for him on the basis that he has participated in a mudharabah partnership. He is entitled to receive a portion from the profit due to his capacity as an entrepreneur (mudharib). Likewise, it is also permissible to give a certain amount of money (commission/fee) or to allocate a determined ratio from the capital to someone who has performed his job on the basis of an agency contract (wakalah). That person, who acts as an agent (wakil); has the right to receive his commission regardless whether the profit from the job is realized or otherwise. For such transaction, the rulings of wakalah with commission is applied and not the rulings of mudharabah.

It is also permissible for both the principal and the agent to agree on investing the assets whereby it is stipulated in the agreement that if the amount of profit reaches a certain limit, the agent shall be entitled to an additional amount apart from the allocated fee. This additional amount can be in the form of a certain percentage from the profit or a specific lump sum and this can be considered as a promise to accord an incentive. As for an agency contract to be valid, it depends on the specified determined and known fee. 


\section{Shariah Issues on Wakalah Bi Al-Istithmar}

a) Guaranteed

Generally, most of the Islamic financial institutions attract investors to invest with them by guaranteeing either the capital or the profit of the investment. There are two point of views on this issue:

i. The Hanafi, Shafi'i, Maliki, Hanbli, Al-Thawri Al-Awza'i, Ishak and Ibn Munzir stated that any provision to guarantee is void because it is contradicted with the content of the contract; which no party shall be liable to indemnify for any matters beyond the control of the contracted property or goods.

ii. Qatadah, Daud al-Zahiri, Al-Syawkani stated that such a condition is legitimate and can be made and applied. Because of this, they applied the principle when there is a consent between parties and on voluntary basis that it is a must.

Principally, the Islamic jurists don't require a guaranteed return on any transaction. It can lead to gharar as the profit and loss of an investment can't be guaranteed. Similarly, IFI's will not guarantee that investors will receive at least the minimum investment profit rate as expected. Investment losses are fully borne by investors unless it is proven that IFIs have been negligent or have breached the terms of the agreement. Investors have the right to designate Islamic financial institutions as authorized representatives to invest in instruments that have the potential to generate at least a minimum profit. Accordingly, if an investor decides to terminate the investment contract and withdraw the entire investment amount, the investor is considered to withdraw the capital management mandate from the Islamic financial institution. In this case, the investor is entitled to the present value of the investment only. This is seen in line with the four sectarian agreements in investment contracts such as mudharabah, in which all sects agree that mudharabah contracts are void or terminated through a clear statement of cancellation, or through the action of a contributor to the revocation of the capital management mandate.

The application of wakalah bi al-Istithmar in Deposit Products offered by BIMB is the deposit products based on wakalah bi al-Istithmar (investment agency). Under this product, the customer will deposit a certain amount of money into an Islamic financial institution provided that the deposit will only be invested in the instrument with the potential to generate a certain rate of return (e.g: $5 \%$ per annum). Islamic financial institutions will act as an agent in investing customer deposits and will be entitled to fees as agreed by both parties.

However, Islamic financial institutions will not guarantee that customers will get at least the minimum expected investment profitability. Any loss will only be borne by the customer unless it is proven that the Islamic financial institution has neglected or had breached the terms of the agreement by investing in an instrument that does not have the potential to generate a minimum profit of $5 \%$ per annum. In addition, if the customer decides to terminate the investment contract before and withdraw all of his or her deposits, he or she will only be entitled to receive the current value of the investment. In this regard, the SAC was referred to the issue as to whether the proposed deposit product based on the wakalah bi al-Istithmar was permissible. This is based on the Resolution made by Shariah Advisory Council of Bank Negara Malaysia. The SAC, in its 2nd special meeting dated June 18, 2007, has resolved that the proposed deposit account under wakalah bi al-Istithmar contract is permissible, subject to the following conditions: 
i. If an Islamic financial institution has breached any terms of the agreement or has negligently invested in an instrument that does not have the potential to generate a minimum profit (e.g. 5\% per annum), the Islamic financial institution must compensate for the amount of the principal investment plus the actual profit (if any); and

ii. If Islamic financial institutions investing in instruments that are expected to generate profits at the rate of at least $5 \%$ a year, but failed to reach the target rate due to problems which are not attributable to the negligent conduct of the Islamic financial institution, such loss will be borne fully by the customer.

\section{b) Wakalah Fee}

The wakalah contract that is permitted by Shariah is either by charging a fee or conducted voluntarily (without a fee). Wages or fees in a wakalah contract must be clearly specified in the form of a certain amount or ratio and agreed upon by the contracting party. It can be settled or paid based on the terms of the agreement or within the agreed timeframe. This approach is based on the actions of the Prophet Muhammad (PBUH) who had sent representatives to collect zakat and they were given salaries or fees or wages for their jobs. Agency is a contract that is permissible in Islam, therefore, an agent doesn't necessarily need to perform the job required and because of this he is entitled to be paid for his work. In hiring agent, the principal can impose certain conditions on the agent, for example, not to perform his duties except for a specified period of time.

In the wakalah structure, the management of the investment fund is allowed to charge fees from capital contributed for the work performed. The fee charged is fixed and unchanged even if the investment made is unsatisfactory. The same approach is also applied if the case of high returns as the fund managers can't claim the surplus fees. The relationship between the fund manager and the investor is based on the wakalah bi al-Istithmar contract. Wakalah bi al-Istithmar is a contract that is based on trust where the fund manager is entrusted to manage the funds as stipulated, to achieve the expected level of profit. Under this contract, the fee is fixed and the fund manager is entitled to receive it whether the investment is profitable or not. Wakalah contract can be arranged for a fee (wakalah bi al-ujrah). If a wakalah contract is arranged with a fee, the agent is entitled to receive the wakalah fee for performing the duties or matters that have been delegated to him. The wakalah fee must be determined and agreed at the time of entering into the wakalah contract. The wakalah fee may be agreed as a fixed amount or as a percentage ratio of a certain amount. The wakalah fee may be paid in the manner agreed upon by the contracting parties as in one lump sum or in several payments.

In addition to the wakalah fee, the contracting parties may agree to an additional fee, over and above the agreed fee (fee of performance). Performance fees may be in the form of excess threshold set for an authorized task. If the wakalah contract involves a sub-agent, the principal and the initial agent may agree with the party responsible for paying the wakalah fee for the sub-agent. If the parties agree that the agent is entitled to a wakalah fee but the rate has not been determined in advance and the task has been fully or partially completed by the agent, he is entitled to a fee based on market rate for a similar task done (ujrah almithl). The agent may waive his right to the fee. Based on this case study conducted in the Wafiyah Investment Account BIMB product, it's found that BIMB has charged fixed fees from the total of investment and these fees don't change according to market whether the 
investment is profitable or not. Nonetheless, no hidden charges will be imposed on investors. In the event of a concealed charge, the contract is classified as gharar and will be burdensome to the investor. If there are other charges, BIMB will notify the investor of such additions without concealing any additional charges. Accordingly, based on observation, it is also discovered that wakalah fees in this product are permissible by Shariah law and didn't burden the investor.

\section{Conclusion}

In conclusion, the wakalah bi al-Istithmar mechanism and principles used in the Wafiyah Investment Account BIMB product is legally acceptable because it didn't conflict with the Islamic principles of mu'amalah and didn't involve with Shariah prohibited elements and instruments as the basis used is Shariah-compliant.

\section{Corresponding Author}

Marina Abu Bakar

Kulliyyah of Shariah and Law, UniSHAMS, 09300, Kuala Ketil, Kedah.

Email: marinaabubakar@unishams.edu.my

\section{References}

Ab. Aziz, M. R. (2013). Islamic Banking and Finance in Malaysia: System, Issues and Challenges. Bandar Baru Nilai: USIM Press.

Ab. Aziz, M. R. (2016). Islamic Commercial Law (Fiqh Muamalat): Theory and Application of Selected Contracts. Bandar Baru Nilai: USIM Press.

Accounting and Auditing Organization for Islamic Financial Institutions (AAOIFI). (2010). Shariah Standards for Islamic Financial Institutions. Bahrain: Dar Al Maiman.

Ayub, M. (2002). Islamic Banking and Finance: Theory and Practice. The State Bank of Pakistan.

Bank Islam Malaysia Berhad. (2020). https://www.bankislam.com/personal-banking/depositand-investments/investments/wafiyah-investment-account/ [Retrieved on 10 April 2020].

Bank Islam Malaysia Berhad (BIMB). (2020). http://www.bankislam.com.my/home/assets/uploads/Wafiyah-PDSFinal_210716.pdf [Retrieved on 10 April 2020].

Bank Islam Malaysia Berhad. (2020). https://www.bankislam.com/wpcontent/uploads/Wafiyah- TC-Premature-withdrawal-2.pdf [Retrieved on 10 April 2020].

Bank Islam Malaysia Berhad. (2020). https://www.bankislam.com/wp-content/uploads/PDSWafiyah_BI.pdf [Retrieved on 10 April 2020].

Bank Negara Malaysia. (2011). Resolution of the Shariah Advisory Council of Bank Negara Malaysia on the Distribution of Surplus in Takaful Scheme and the Application of Wakalah Contract in Deposit Instrument. Kuala Lumpur.

Bank Negara Malaysia. (2015). Wakalah Concept Paper. Available at: http://www.bnm.gov.my/guidelines/05_shariah/Wakalah.pdf [Retrieved on 10 April 2020].

Bank Negara Malaysia. (2015). Shariah Advisory Council. http://www.sacbnm.org/wpcontent/uploads/2018/03/66.E.pdf. [Retrieved on 10 April 2020]. 
Furqani, D. (2013). "The Contract of Wakalah and Its Application in Islamic Finance". Fatwa in Islamic Finance-ISRA \& Bloomberg, Issue 8, p. 6.

Hasan, A. (2011). Fundamentals of Shariah Islamic Finance. Kuala Lumpur: IBFIM.

Maybank Islamic. (2020). Fatwa: Application of Wakalah bi al-Istithmar.

https://www.maybank.com/islamic/en/coe/fatwa/islamic-

banking/application_of_wakalah_bi-al-istithmar.page? [Retrieved on 11 April 2020].

Ibrahim, N. Z. A., Muhammad. (1997). Al-Asbah wa Al-Naza'ir 'ala Mazhab Abi Hanifah alNu'man. Beirut: Dar al-Kutub al-'Ilmiyyah. 